\title{
Sistem UMKM Online Produk Penjualan Kampoeng Sejarah Kota Malang Berbasis Website
}

\author{
Putra Prima Arhandi ${ }^{*}, 1$, Anisa Taufika Firdausi ${ }^{2}$, Kadek Suarjuna Batubulan ${ }^{3}$, \\ Ridwan Rismanto ${ }^{4}$, Banni Satria Andoko 5 \\ 1,2,3,4,5 Jurusan Teknologi Informasi, Politeknik Negeri Malang \\ e-mail: ${ }^{* 1}$ putraprima@polinema.ac.id, ${ }^{2}$ annisa.taufika@polinema.ac.id, ${ }^{3}$ kadeksuarjuna87@polinema.ac.id, \\ rismanto@polinema.ac.id, ${ }^{4}$ ando@polinema.ac.id
}

\begin{abstract}
Abstrak
Pandemi Covid-19 yang menerjang Indonesia berpengaruh terhadap penurunan kinerja sektor ekonomi yang sangat signifikan. Sebagian besar masyarakat kelas menengah ke bawah merasakan dampak yang sangat merugikan contohnya di kampoeng sejarah Kota Malang. Perekonomian masyarakat di Kampoeng Sejarah sangatlah terpuruk karena penurunan penghasilan yang sangat tajam bagi kehidupan sehari-hari juga dengan adanya kebijakan pemerintah yang sering berubah-ubah. Salah satu solusi untuk mengatasi permasalahan tersebut adalah dengan cara menjembatani hasil produksi kampoeng sejarah dan konsumen melalui media elektronik secara online. Sistem yang akan dibuat menampilkan menu yang dapat memudahkan pengguna dalam mengakses informasi yang dibutuhkan baik pengelola maupun konsumen. Setelah sistem selesai dibuat, maka akan dilakukan pengujian sistem kepada para user dengan cara pemberian kuesioner dan presentasi langsung ke Kampoeng Sejarah. Dari hasil pengujian tersebut didapatkan bahwa dari 46 user yang menggunakan sistem online tersebut ada 2 pengguna yang tidak setuju dengan sistem sesuai dengan kebutuhan dikarenakan masih akan adanya pengembangan sistem yang nanti akan di terapkan. Maka jika diambil dari hasil prosentase pengguna bahwa yang setuju sebesar 95\% dan yang tidak setuju ada 5\%.
\end{abstract}

Kata kunci : Kampoeng Sejarah, UMKM, sistem online

\section{PENDAHULUAN}

Badai pandemi Covid-19 yang menerpa Indonesia membuat sektor ekonomi mengalami penurunan sangat signifikan bahkan sebagian besar kelas menengah ke bawah menjadi golongan yang sangat dirugikan. Dampak dari pandemi ini salah satunya banyak masyarakat yang menggantungkan dana bansos dari pemerintah yang masih belum bisa memenuhi kebutuhan masyarakat seperti di kawasan Kampoeng Sejarah yang berada di kelurahan Sumbersari Kota Malang. Selama masa pandemi tidak lagi memproduksi barang dikarenakan konsumen yang biasanya didominasi oleh anak-anak kuliah maupun masyarakat luar tidak lagi berkunjung sehingga banyak masyarakat Kampoeng Sejarah yang merasakan penurunan pendapatan sangat tajam. Selain itu juga dipengaruhi adanya kebijakan pemerintah yang memberikan batasanbatasan selama berdagang seperti pengaturan jam tutup, pembatasan berkunjung sampai pembatasan sosial berskala besar (PSBB) [1].

Salah satu solusi yang dilakukan masyarakat Kampoeng Sejarah untuk mengatasi permasalahan tersebut selama ini adalah dengan menjual hasil produksi keluar wilayah Kampoeng Sejarah dengan cara menitipkan ke pasar-pasar atau ke toko yang banyak pengunjungnya. Namun hal ini pun tidak berjalan dengan maksimal karena timbul banyak permasalahan baru diantaranya masyarakat juga sering mengalami kerugian karena harus mengeluarkan biaya sewa tempat sementara hasil produksi yang terjual tidak memenuhi kebutuhan.

Berdasarkan hasil pengamatan dan informasi yang didapatkan, maka dirancang suatu sistem yang dapat menjembatani antara produksi Kampoeng Sejarah dengan konsumen melalui media elektronik secara online yaitu Sistem UMKM Online Produk Penjualan Kampoeng Sejarah Kota Malang Berbasis Website. Sistem tersebut diharapkan dapat menyelesaikan permasalahan dalam pemasaran hasil produk yang di buat oleh masyarakat dengan cara pemasaran secara online sehingga bisa mengurangi terjadinya pengangguran dan gulung tikar kegiatan usaha dalam masa pandemi COVID-19 ini [2]. Setelah sistem dibuat, maka akan diberikan edukasi melalui seminar kepada masyarakat sehingga akan mempermudah dalam menjalankan sistem tersebut misalnya dapat melakukan update produk secara mandiri dan bertransaksi secara online [3]. 


\section{METODE}

\subsection{Bagan Sistem}

Dalam pelaksanaan kegiatan pelatihan ini, dibuat bagan yang akan menjadi acuan dalam menyusun menu sistem yang dapat mempermudah pemahaman user sebagai berikut :

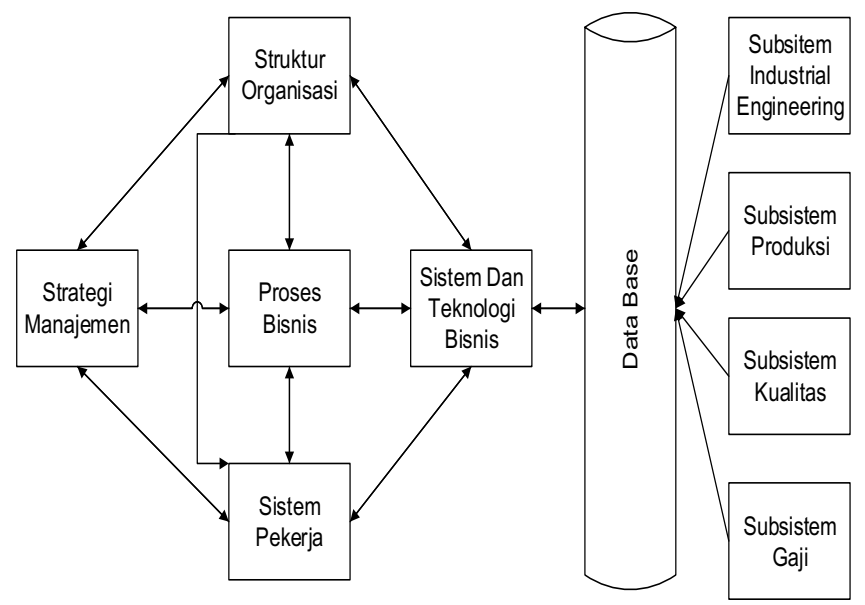

Gambar 1 Bagan Sistem

Di bawah ini adalah gambaran IPTEK yang akan digunakan pada sistem dan sosialisasi yang dalamnya terdapat:

- Manajemen Strategi

- Struktur Organisasi

- Sistem Pekerja

- Sistem Teknologi Informasi

Dari beberapa sistem diatas maka semua akan diproses bisnis dan disimpan di dalam database berupa:

- Subsistem Industrial Engineering

- Subsistem Produksi

- Subsistem Kualitas

- Subsistem Gaji

\section{HASIL DAN PEMBAHASAN}

Berikut adalah menu tampilan awal :

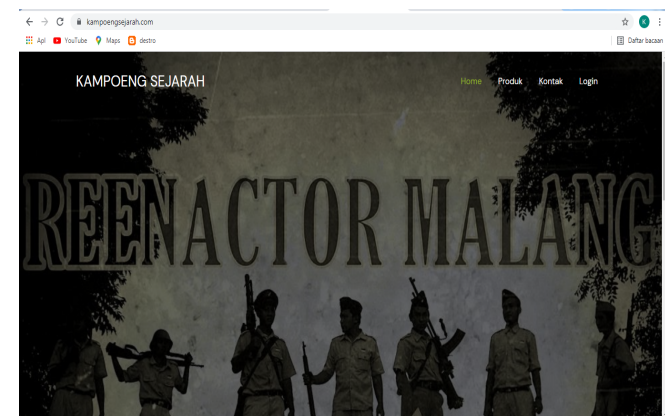

Gambar 2 Tampilan awal
Pada halaman tampilan awal terdapat menu Home, Produk, Kontak dan Login yang mempunyai fungsi masing-masing, sebagai berikut :

a. Home : berfungsi untuk mengetahui deskripsi tentang Kampoeng Sejarah.

b. Produk : berfungsi untuk menjual dan mempromosikan hasil dari produksi Kampoeng Sejarah.

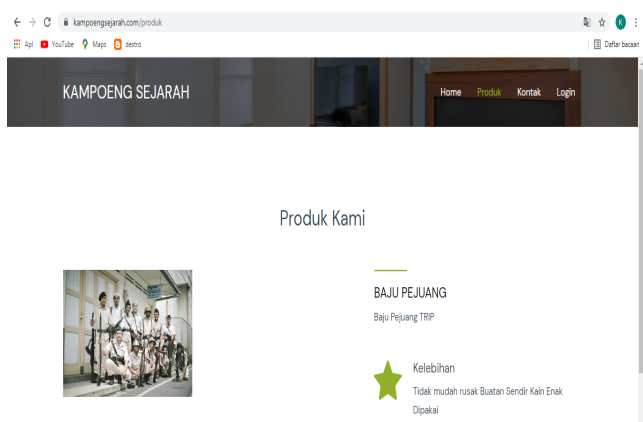

Gambar 3 Produk

c. Kontak: Berfungsi untuk memberikan informasi personal yang dapat dihubungi di Kampoeng Sejarah terdiri dari nama, alamat, nomer handphone dan email beserta dengan saran kritik.

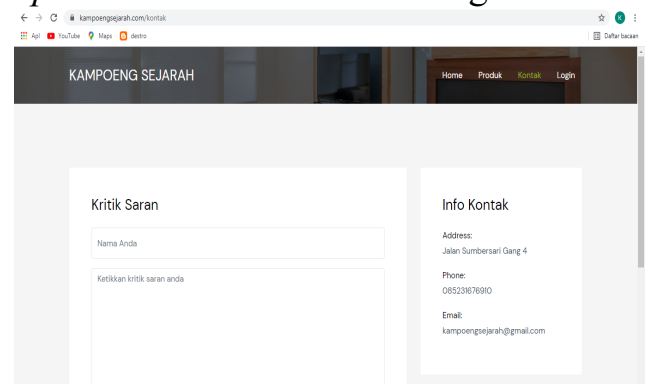

Gambar 4 Kontak

d. Login: berfungsi untuk mengedit semua halaman yang ada di dalam sistem untuk bisa dikelola sesuai dengan yang diinginkan. Didalam login juga ada pembagian pengguna yaitu apakah sebagai admin atau anggota.

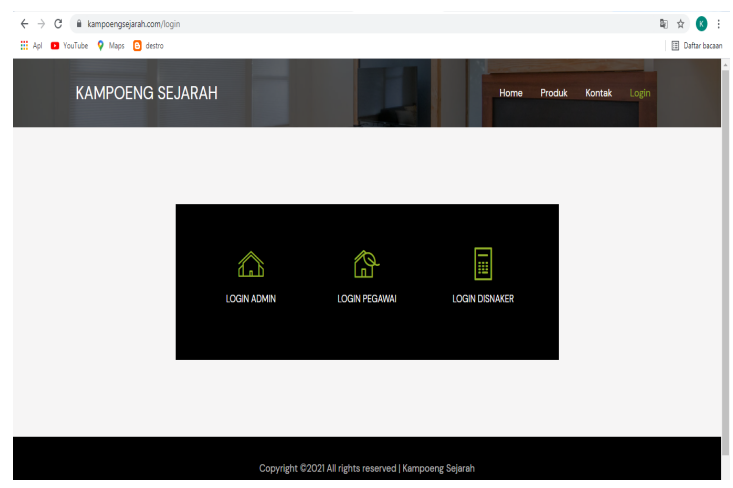

Gambar 5 Login

Dari hasil pembuatan sistem sesuai penjabaran dan gambar diatas maka dilakukan pengujian sistem menggunakan kuesioner yang 
disebarkan kepada 46 user masyarakat Kampoeng Sejarah dengan hasil sebagai berikut :

Tabel 1 pengujian sistem

\begin{tabular}{|c|l|c|c|}
\hline \multirow{2}{*}{ No. } & \multicolumn{1}{|c|}{ Pertanyaan } & \multicolumn{2}{|c|}{ Tanggapan } \\
\cline { 3 - 4 } & \multicolumn{1}{|c|}{ Setuju } & $\begin{array}{c}\text { Tidak } \\
\text { Setuju }\end{array}$ \\
\hline 1 & Sistem mudah dipahami & 46 & \\
\hline 2 & Penggunaan menu sesuai & 46 & \\
\hline 3 & Sistem sesuai kebutuhan & 44 & 2 \\
\hline 4 & $\begin{array}{l}\text { Sistem mempunyai kemampuan } \\
\text { dan fungsi sesuai dengan yang } \\
\text { diharapkan }\end{array}$ & 46 & \\
\hline 5 & $\begin{array}{l}\text { Sistem bermanfaat bagi } \\
\text { pengguna }\end{array}$ & 46 & \\
\hline 6 & $\begin{array}{l}\text { Apakah mudah menghindari } \\
\text { kesalahan dalam penggunaannya }\end{array}$ & 46 & \\
\hline
\end{tabular}

Dari hasil kuesioner yang sudah dirumuskan pada Tabel 1, didapatkan bahwa dari 46 pengguna yang menggunakan sistem tersebut ada 2 pengguna yang tidak setuju dengan sistem sesuai dengan kebutuhan dikarenakan masih akan adanya pengembangan sistem yang nanti akan di terapkan. Dengan demikian prosentase pengguna sistem yang setuju sebesar $95 \%$ dan yang tidak setuju sebesar 5\%.

\section{KESIMPULAN}

Pembuatan sistem UMKM online yang diterapkan pada masyarakat Kampoeng Sejarah Kota Malang sangat bermanfaat dalam menunjang keberlangsungan kegiatan produksi dan ekonomi dimasa pandemi COVID-19. Masyarakat dapat melakukan berbagai transaksi ekonomi secara mudah dan mampu memperluas daya jangkau pemasaran produknya. Dari hasil pengujian sistem terhadap 46 pengguna melalui kuesioner dan demo langsung, maka didapatkan hasil sebesar 95\% yang setuju terhadap penerapan sistem ini dan kurang setuju sebesar $5 \%$.

\section{SARAN}

Dalam upaya mengembangkan hasil pelatihan lebih lanjut, maka dapat dilakukan evaluasi terhadap implementasi penggunaan sistem baik oleh masyarakat Kampoeng Sejarah maupun user pembeli. Sistem dapat dikembangkan sesuai kebutuhan dan kemudahan penggunaannya sehingga dapat diketahui manfaat program pelatihan dalam jangka panjang dan berkesinambungan.

\section{UCAPAN TERIMA KASIH}

Penulis mengucapkan terima kasih kepada Politeknik Negeri Malang yang telah memberi dukungan moral dan dana terhadap program pengabdian masyarakat ini. Terima kasih juga untuk Mitra di Kampoeng Sejarah Kota Malang yang telah memberikan dukungan moral dan membantu jalannya pelaksanaan kegiatan pengabdian pada masyarakat ini.

\section{DAFTAR PUSTAKA}

[1] Bawden, D., 2018, Information and Digital Literacies: A Review of Concepts, Journal of Documentation, 57(2), 218-259.

[2] Metzger, Miriam J. et.al.(edt), 2008, Introduction: Digital Media, Youth, and Credibility. Cambridge: MIT Press.

[3] Jenkins, H., 2019, Confronting The Challenges of Participatory Culture: Media Education for the 21st Century, Illinois: MacArthur Foundation. 